\title{
INFLUENCE OF ULTRASOUND PRETREATMENT ON CONVECTIVE DRYING OF PINEAPPLE
}

\author{
J.L.G. CORRÊA ${ }^{1 *}$, M.C. RASIA ${ }^{2}$, J.V. GARCIA-PEREZ ${ }^{3}$, A. MULET ${ }^{3}$, J.A. CÁRCEL ${ }^{3}$ \\ ${ }^{1}$ Universidade Federal de Lavras, Departamento de Ciência dos Alimentos \\ ${ }^{2}$ Universidad Nacional de Entre Ríos, Facultad de Ciencias de la Alimentación \\ ${ }^{3}$ Universitat Politècnica de València, Depto. de Tecnología de Alimentos \\ *e-mail: jefferson@dca.ufla.br
}

\begin{abstract}
The convective drying is a slow operation. Several techniques has been studied to increase the kinetics of process such as the pretreatments in liquids or the application of high intensity ultrasound during both, pretreatment or convective drying. In this work, the influence of the pretreatment (with distilled water $\left(20\right.$ and $40 \mathrm{~min}$ at $25^{\circ} \mathrm{C}$ ) on convective drying $\left(40{ }^{\circ} \mathrm{C}, 1 \mathrm{~m} \mathrm{~s}^{-1}\right)$ of pineapple slices $(2.0 \mathrm{~cm}$ diameter, $0.5 \mathrm{~cm}$ thickness) was studied. The application of ultrasound during pretreatment $(55.5 \mathrm{~W} / \mathrm{L}, 40$ $\mathrm{kHz})$ or during convective drying $\left(31 \mathrm{~kW} \mathrm{~m}^{-3} ; 21.8 \mathrm{kHz}\right)$ was also addressed. The results showed that the application of ultrasound during the pretreatment and during drying increased water transport and reduced the drying time. The use of ultrasound in the pretreatment or in the convective drying could improve drying processes.
\end{abstract}

\section{INTRODUCTION}

Drying is one of the oldest ways for food preservation being the convective drying one of the most extended techniques (MUJUMDAR, 2006). It is based on the moisture removal by the contact of the wet food with a heated air current. It is widely used for drying fruits like pineapple (SANTOS \& SILVA, 2009; CORRÊA et al., 2011, 2012; RAMALHO \& MASCHERONI, 2012). However, convective drying involves the exposure of the food to high temperature for a long time with consequent degradation of quality characteristics as nutrient contents, color and mechanical properties (CORRÊA et al., 2012; KUROZAWA et al., 2014).

In order to minimize these undesirable effects, some alternatives have been explored. Among them, it can be highlighted the use of pretreatments in liquids as distilled water, assisted or not by high intensity ultrasound (AZOUBEL et al., 2010; FERNANDES et al., 2008; FERNANDES and RODRIGUES, 2007) or the use of convective drying assisted by power ultrasound (OZUNA et al., 2011; CÁRCEL et al., 2012; GAMBOA-SANTOS et al., 2014).

The goal of this work was the study of the influence of the ultrasonically pretreatment with distilled water of pineapple in the later convective drying kinetics, carried out also with and without the ultrasound application. 


\section{MATERIAL AND METHODS}

\subsection{Sample preparation}

The pineapple (Ananas comosus) used in this work was the new hybrid 73-114, known as Golden Pineapple or MD2, produced in Costa Rica and bought in Valencia, Spain. To minimize the influence of natural variability of the raw material, the fruits were selected with a similar

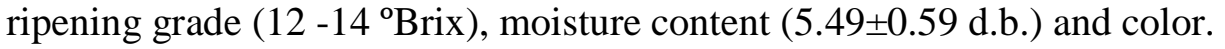

The fruits were cut in three parts in the transversal way and only the central part was considered neglecting the upper and the bottom parts. This is due to the different sugar content from one extreme to another (RAMALLO \& MASCHERONI, 2012). Disks shaped samples of $2.0 \mathrm{~cm}$ diameter and $0.5 \mathrm{~cm}$ thickness were obtained from the pulp, with the aid of a cork-borer and wrapped until drying experiments.

\subsection{Pretreatments}

After the preparation, a set of samples was immersed in a bath of distilled water at $25{ }^{\circ} \mathrm{C}$ assisted by ultrasound $(55.5 \mathrm{~W} / \mathrm{L}, 40 \mathrm{kHz}$ ) for 20 (PUS-20) and 40(PUS-40) min. The relation fruit/solution was about $1 / 300(\mathrm{w} / \mathrm{w})$. The temperature was maintained by recirculation of a cooling fluid in the jacket of the bath. Another set of samples was not pretreated (PUS-0).

\subsection{Drying experiments}

The experiments were carried out in the drying system presented in Figure 1, previously described (CÁRCEL et al., 2007, 2011; GARCÍA-PÉREZ et al., 2011; OZUNA et al., 2011).

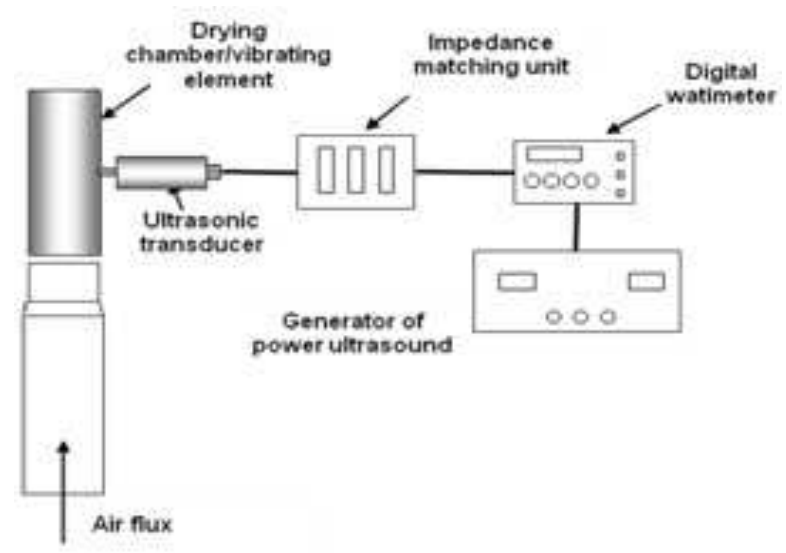

Figure 1 - Scheme of the ultrasonically assisted drier 


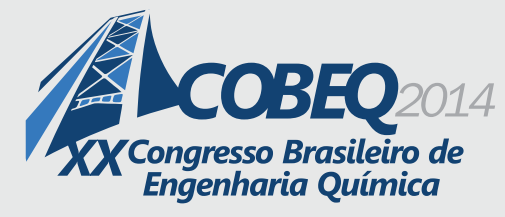

19 a 22 de outubro de 2014

Florianópolis/SC

For each run, forty samples were put in fixed positions in a sample holder allowing the free flow of air around them. This support was then introduced in the system. The drying chamber was an aluminum cylindrical vibrating element (internal diameter $100 \mathrm{~mm}$, height $310 \mathrm{~mm}$ and thickness $10 \mathrm{~mm}$ ) that works as an air-borne ultrasonically activated drying chamber. The cylinder is driven by a piezoelectric composite transducer $(21.8 \mathrm{kHz})$; thus, the ultrasonic system was able to generate a high-intensity ultrasonic field with an average sound pressure of $154.3 \mathrm{~dB}$ (measured using an ultrasonic power of $31 \mathrm{kWm}^{-3}$ and air stagnant conditions) The drier operates automatically and a PC supervises the whole process; the air velocity and temperature were controlled using a PID algorithm. A scale allowed the samples to be weighed at preset times by using two pneumatic moving arms and obtaining the drying kinetics for each case.

Drying experiments were carried out using an air velocity of $1.0 \mathrm{~m} \mathrm{~s}^{-1}$ and a temperature of $40{ }^{\circ} \mathrm{C}$, with (PUS-0-DUS; PUS-20-DUS and PUS-40-DUS) and without (PUS-0-D; PUS-20-D and PUS-40-D) application. In the case of ultrasonic assisted $(21.8 \mathrm{kHz})$ drying experiments, an ultrasonic power density of $31 \mathrm{~kW} \mathrm{~m}^{-3}$ (electrical power applied to transducer divided by the drying chamber volume) was used. The drying was stopped when samples lost the $80 \%$ of the initial weight. Each drying condition tested was carried out by triplicate.

\section{RESULTS AND DISCUSSION}

The immersion in distilled water assisted by ultrasound increased the moisture content of the samples from 5.26 to 9.00 (d.b.) due to the fact that the fruit present higher osmotic pressure. On the other hand, it improved the further drying process with and without ultrasound assistance (Figures 2 and 3). Regarding the convective drying without ultrasound assistance (PUS-0-D, PUS-20-D and PUS-40-D), it could be observed (Figure 2) that the pretreatment increased the dehydration with consequent shorter drying time. Similar results were observed in previous works. (AZOUBEL et al., 2010; FERNANDES et al, 2008; FERNANDES and RODRIGUES, 2007). Among the periods of treatment, that performed at 20 min presented shorter drying time. As a result, it is considered the best condition. It can be assumed that the ultrasound pretreatment causes structural changes in the food (LEE; FENG, 2011) like the micro channels formation (CÁRCEL et al. 2012). The changes within $20 \mathrm{~min}$ of treatment aids the further drying. However, a longer time treatment could have therefore greater structure damage that does not favor the drying process.

The experiments performed with ultrasound assistance, with or without pretreatment (PUS0-DUS, PUS-20-DUS and PUS-40-DUS), presented shorter drying time with respect to the drying without assistance. Drying time for a conventional convective drying at $40{ }^{\circ} \mathrm{C}$ was about 8 to 12 hours and the convective drying assisted by ultrasound was about 5.8 to 6.3 hours, i.e, the use of ultrasound in drying reduced until $50 \%$ of the drying time. The cavitation and the sponge effect, characteristics of drying assisted by ultrasound (CÁRCEL et al., 2007, 2011; GARCÍAPÉREZ et al., 2011; OZUNA et al., 2011) reduces the external and the internal resistance to drying. The use of the pretreatment shows a trend to decrease drying time. 


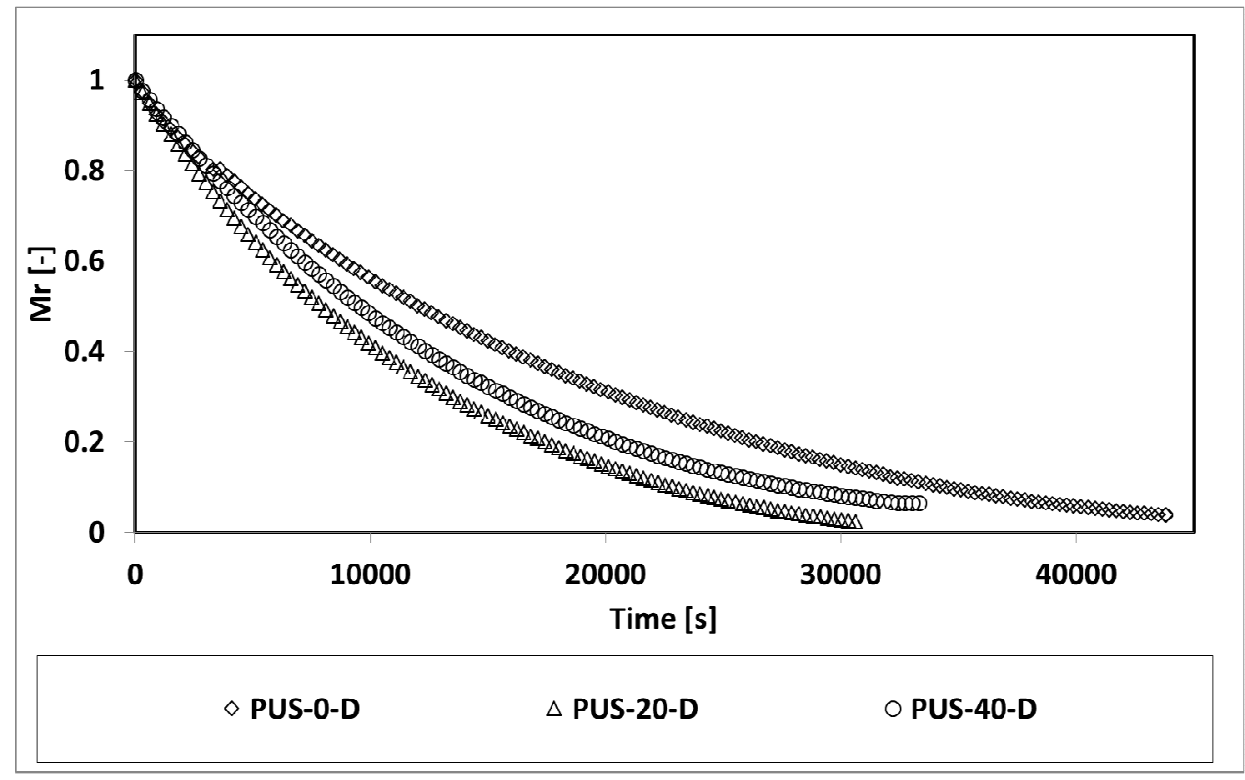

Figure 2 - Drying kinetics of pineapple slices at $40{ }^{\circ} \mathrm{C}$. Conv means convective drying, USDW means immersion in distilled water assisted by ultrasound

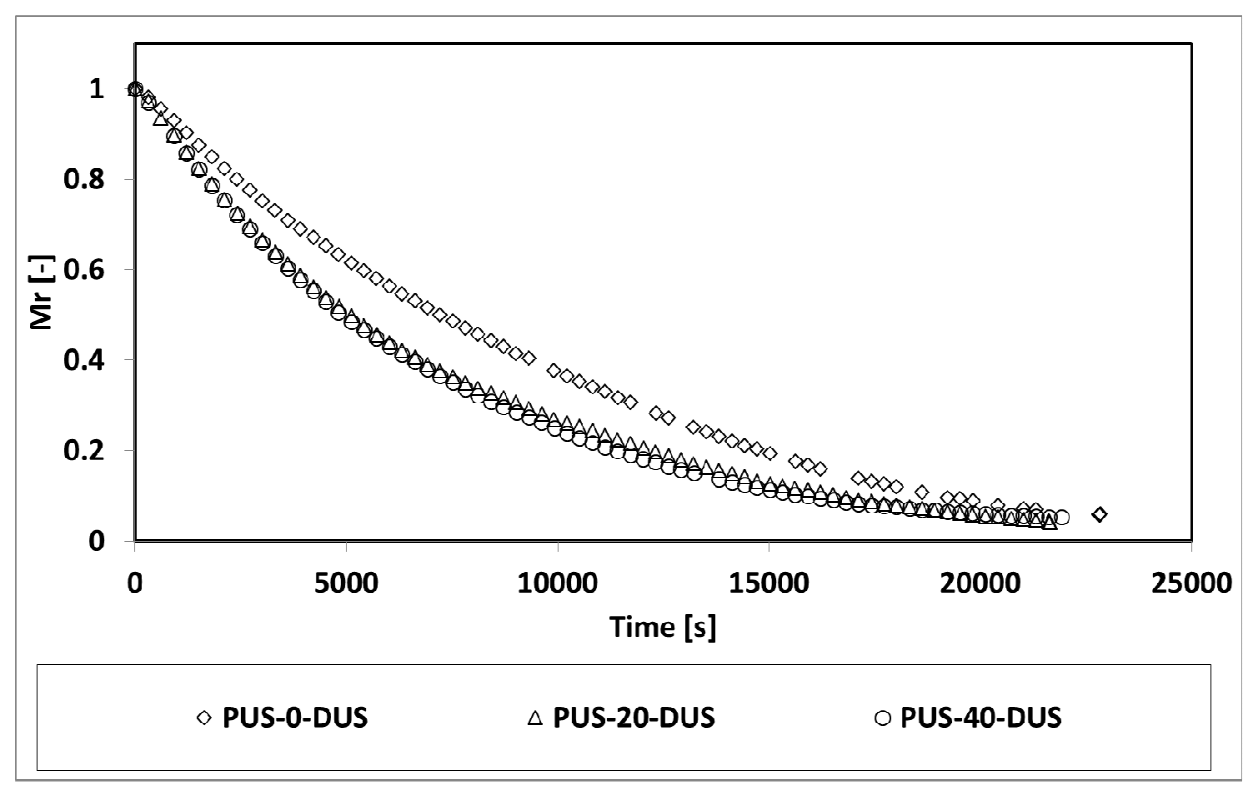

Figure 3 - Drying kinetics of pineapple slices at $40^{\circ} \mathrm{C}$, assisted by ultrasound. Conv means convective drying, USDW means immersion in distilled water assisted by ultrasound 


\section{CONCLUSION}

The pretreatment of pineapple with ultrasound in distilled water affected the later drying increasing the drying rate probably by affecting the internal structure of fruit. Moreover, the ultrasonically assisted drying improved also the drying kinetics. The combination of pretreatment with ultrasound and drying also with ultrasound application provided the fastest process. More research is needed to determine how ultrasound affects internal structure of pineapple.

\section{REFERENCES}

AZOUBEL, P. M. et al. Effect of ultrasound on banana cv Pacovan drying kinetics. Journal of Food Engineering, v. 97, n. 2, p. 194-198, mar. 2010.

CÁRCEL, J. A. et al. Influence of High-Intensity Ultrasound on Drying Kinetics of Persimmon. Drying Technology, v. 25, n. 1, p. 185-193, 12 fev. 2007.

CÁRCEL, J. A. et al. Improvement of Convective Drying of Carrot by Applying Power Ultrasound-Influence of Mass Load Density. Drying Technology, v. 29, n. 2, p. 174-182, 17 jan. 2011.

CÁRCEL, J. A.; BENEDITO, J.; MULET, A. Food process innovation through new technologies : Use of ultrasound. Journal of Food Engineering, v. 110, p. 200-207, 2012.

CORRÊA, J. . L. G. . et al. Drying of Pineapple by Microwave-Vacuum with Osmotic Pretreatment. Drying Technology, v. 29, n. 13, p. 1556-1561, out. 2011.

CORRÊA, J. L. G. et al. The Influence of Ethanol on the Convective Drying of Unripe, Ripe, and Overripe Bananas. Drying Technology, v. 30, n. 8, p. 817-826, jun. 2012a.

CORRÊA, J. L. G. et al. The Influence of Ethanol on the Convective Drying of Unripe, Ripe, and Overripe Bananas. Drying Technology, v. 30, n. 8, p. 817-826, 15 jun. 2012 b.

FERNANDES, F. A N.; LINHARES, F. E.; RODRIGUES, S. Ultrasound as pre-treatment for drying of pineapple. Ultrasonics sonochemistry, v. 15, n. 6, p. 1049-54, set. 2008.

FERNANDES, F. A. N.; RODRIGUES, S. Ultrasound as pre-treatment for drying of fruits: Dehydration of banana. Journal of Food Engineering, v. 82, n. 2, p. 261-267, set. 2007.

FRIAS, J. et al. Influence of drying by convective air dryer or power ultrasound on the vitamin C and $\beta$-carotene content of carrots. Journal of agricultural and food chemistry, v. 58, n. 19, p. 10539-44, 13 out. 2010. 
GAMBOA-SANTOS, J. et al. Air-borne ultrasound application in the convective drying of strawberry. Journal of Food Engineering, v. 128, p. 132-139, maio 2014.

GARCÍA-PÉREZ, J. V. et al. Modeling Ultrasonically Assisted Convective Drying of Eggplant. Drying Technology, v. 29, n. 13, p. 1499-1509, out. 2011.

KUROZAWA, L. E. et al. Ascorbic acid degradation of papaya during drying: Effect of process conditions and glass transition phenomenon. Journal of Food Engineering, v. 123, p. 157-164, fev. 2014.

LEE, H.; FENG, H. Effect of ultrasound on food quality. In: FENG, H.; BARBOSA-CANOVAS, G.; WEISS, J. (Eds.). ULTRASOUND TECHNOLOGIES FOR FOOD AND

BIOPROCESSING. Food Engineering Series. New York, NY: Springer New York, 2011. p. $559-582$.

MUJUMDAR, A. S. Handbook of Industrial Drying. 3rd Editio ed. [s.1.] Taylor \& Francis Group, 2006. p. 1279

OZUNA, C. et al. Improvement of water transport mechanisms during potato drying by applying ultrasound. Journal of the science of food and agriculture, v. 91, n. 14, p. 2511-7, nov. 2011.

RAMALLO, L. A.; MASCHERONI, R. H. Quality evaluation of pineapple fruit during drying process. Food and Bioproducts Processing, v. 90, n. 2, p. 275-283, abr. 2012.

SANTOS, P. H. S.; SILVA, M. A. Kinetics of L -Ascorbic Acid Degradation in Pineapple Drying under Ethanolic Atmosphere. Drying Technology, v. 27, n. 9, p. 947-954, 18 ago. 2009.

\section{ACKNOWLEDGEMENTS}

The authors would like to thanks CAPES and FAPEMIG, from Brazil, and Ministerio de Economia y Competitividad and FEDER (DPI2013-37466-C03-03), from Spain, by the financial support to this work. 